\title{
Zpráva o grantovém projektu Emoční kreativita a kognitivní deficity u seniorů
}

\section{Radek Trnka}

V prosinci 2020 byl ukončen tříletý grantový projekt Emoční kreativita a kognitivní deficity u seniorů řešený na Pražské vysoké škole psychosociálních studií (podpořený Grantovou agenturou ČR, projekt č. 18-26094S). Hlavním cílem tohoto projektu bylo prozkoumat vztah mezi emoční kreativitou a deficitem kognitivních funkcí u seniorů. Emoční kreativita patří mezi prozatím poměrně málo prozkoumané oblasti psychologie. Je to soubor kognitivních dovedností a osobnostních rysů vztahujících se $\mathrm{k}$ originalitě emočního prožívání. Psychometrický test "Emotional Creativity Inventory" (Averill, 1999) je v současné době jediným nástrojem na měření emoční kreativity a obsahuje tři hlavní subškály/komponenty: Preparedness (tj. nakolik jedinec přemýšlí o vlastních emočních reakcích), Novelty (tj. nakolik jedinec vnímá své emoce jako unikátní a originální) a Effectiveness/Authenticity (tj. jak efektivně jedinec reaguje v situacích vyžadujících neobvyklé emoční reakce).

Projekt byl zahájen teoretickou př́pravou, v jejímž rámci byly zpracovány a publikovány tři přehledové studie. První se zaměřením na emoční kreativitu (Kuška et al., 2020), druhá shrnující neuropsychologický výzkum vztahu mezi amygdalami a emocionalitou u Parkinsonovy choroby (Trnka et al., 2018) a třetí shrnující výzkum neuropsychiatrických symptomů a kreativity u neurodegenerativních onemocnění (Nikolai et al., 2020).

V rámci projektu byla realizována dvě empirická šetření. První šetření prozkoumalo emoční kreativitu a kognitivní deficity u populace zdravých českých seniorů $(n=187,55)$ pomocí sebeposuzovacích psychometrických nástrojů. Výsledky ukázaly na to, že senioři s deficity exekutivních funkcích či vyšší apatií měli nižší skór u komponenty Preparedness - tedy měli tendenci méně přemýšlet o vlastních emočních reakcích (Trnka et al., 2019). Srovnání vzorku seniorů se vzorky jedinců mladší a střední dospělosti pak ukázalo, že senioři měli nižší skór v komponentách Preparedness (tj. nakolik jedinec přemýšlí o vlastních emočních reakcích) a Novelty (tj. nakolik vnímá jedinec své emoce jako unikátní a originální), přičemž úroveň komponenty Effectiveness/Authenticity (tj. jak efektivně jedinec reaguje v situacích vyžadujících neobvyklé emoční reakce) byla srovnatelná s jedinci mladší a střední dospělosti (Trnka et al., 2020).

Ve druhém empirickém šetření pak byla, kromě testu "Emotional Creativity Inventory" (Averill, 1999), využita komplexní neuropsychologická baterie, která se v klinické neuropsychologii v praxi používá pro diagnostiku kognitivního deficitu u počínajících neurodegenerativních onemocnění (Nikolai et al., 2021). Výsledky získané u vzorku 40 seniorů bez diagnózy neurodegenerativního onemocnění byly porovnány s klinickým vzorkem 22 pacientů s Parkinsonovou chorobou bez kognitivních deficitů. Pacienti s Parkinsonovou chorobou vykazovali nižší skóry u kognitivních testů a zároveň také nižší emoční kreativitu u komponenty Preparedness (měli tendenci méně přemýšlet o vlastních emočních reakcích). Co bylo velmi překvapivé, komponenta Preparedness nekorelovala $\mathrm{s}$ výsledky kognitivních testů. To by mohlo znamenat, že deficity v emoční kreativitě mohou být novým, svébytným indikátorem raných stádií neurodegenerativních onemocnění. 
V tuto chvíli se ale jedná pouze o první předběžná zjištění a je třeba uskutečnit další studie na rozsáhlejších klinických vzorcích.

Hlavním řešitelem tohoto grantového projektu byl Tomáš Nikolai, Ph.D., dalšími členy řešitelského týmu pak byli: Radek Trnka, Ph.D., Martin Kuška, Ph.D. a doc. Karel Balcar. Na projektu dále spolupracovali Mgr. Tereza Slavíčková, Inna Čábelková, Ph.D., Zdeněk Šulc, Ph.D., Mgr. Josef Mana, Mgr. Kateřina Čechová a Mgr. Vladimíra Plzáková.

\section{Literatura}

Averill, J. R. (1999). Individual differences in emotional creativity: Structure and correlates. Journal of Personality, 67(2), 331-371. https://doi.org/10.1111/1467-6494.00058

Kuška, M., Trnka, R., Mana, J., \& Nikolai, T. (2020). Emotional creativity: A meta-analysis and integrative review. Creativity Research Journal, 32(2), 151-160.

https://doi.org/10.1080/10400419.2020.1751541

Nikolai, T., Kuška, M., \& Trnka, R. (2020). Neuropsychiatrické příznaky a kreativita u neurodegenerativních onemocnění. Československá psychologie, 64(5), 564-577.

Nikolai, T., Sulc Z., Balcar, K., Kuška, M., Plzakova, V., Slavickova, T., \& Trnka, R. (2021). Decreased emotional creativity and its relationship with cognitive functions in Parkinson's disease: A preliminary study. Applied Neuropsychology: Adult (Accepted Manuscript)

Trnka, R., Cabelkova, I., Kuška, M., \& Nikolai, T. (2019). Cognitive decline influences emotional creativity in the elderly. Creativity Research Journal, 31(1), 93-101. https://doi.org/10.1080/10400419.2019.1577205

Trnka, R., Hasto, J., Cabelkova, I., Kuška, M., Tavel, P., \& Nikolai, T. (2018). Amygdala and emotionality in Parkinson's disease: An integrative review of the neuropsychological evidence. Neuroendocrinology Letters, 39(2), 105-110.

Trnka R., Kuška M., \& Cabelkova I. (2020). Emotional creativity across adulthood: Age is negatively associated with emotional creativity. Studia Psychologica, 62(2), 164-177. https://doi.org/10.31577/sp.2020.02.798

\section{Údaje o autorovi}

Ing. Radek Trnka, Ph.D. pracuje jako samostatný výzkumný pracovník na Pražské vysoké škole psychosociálních studií a na Institutu sociálního zdraví Cyrilometodějské teologické fakulty Univerzity Palackého v Olomouci. Zaměřuje se na výzkum v oblasti psychologie emocí, kreativity a zvládání stresu.

\section{Kontaktní údaje:}

adresa: Pražská vysoká škola psychosociálních studií, Milánská 471, Praha 15, 109 00;

e-mail: trnkar@volny.cz;

Research Gate profil: https://www.researchgate.net/profile/Radek_Trnka/

Trnka, R. (2021). Zpráva o grantovém projektu Emoční kreativita a kognitivní deficity u seniorů. E-psychologie, 15(1), 94-95. https://doi.org/10.29364/epsy.396 